\title{
Peningkatan Pembelajaran Keterampilan Berbicara Melalui Media Gambar Seri di Kelas III SDN 17 Batang Anai Kabupaten Padang Pariaman
}

\section{Surida}

\begin{abstract}
Usually, students feel reluctant to speak in front of classroom. It is caused by learning Bahasa that only focus on reading and writing skill, but less on speaking skill. This research is aimed to improve speaking skill of elementary students grade III in SDN 17 Batang Anai Kabupaten Padang Pariaman by implementing serial pictures media. This is a class action research that consists of two cycles including four steps: planning, action, observation, and reflection. Data of research were obtained through observation, interview, and test. Obtained data were analyzed quantitatively and qualitatively. Learning output of students is improved in each cycle.In cycle I, the percentage of students' speaking skill is $53.3 \%$. Meanwhile in cycle II, the percentage of students' speaking skill is $86 \%$. Hence, it can be concluded that Bahasa learning that use serial pictures media can improve speaking skill of elementary students grade III.
\end{abstract}

Keyword: serial picture, speaking skill

Copyright () 2016 IICET (Padang - Indonesia) - All Rights Reserved Indonesian Institute for Counseling, Education and Theraphy (IICET)

\section{PENDAHULUAN}

Pada rambu-rambu pembelajaran bahasa Indonesia dalam KTSP pertama dijelaskan bahwa tujuan pembelajaran bahasa Indonesia adalah mampu berkomunikasi secara efektif dan efesien sesuai dengan etika yang berlaku baik secara lisan maupun tulis. Berpedoman pada isi KTSP tersebut, tujuan pembelajaran bahasa Indonesia mencakup empat aspek keterampilan berbahasa yaitu keterampilan menyimak, keterampilan berbicara, keterampilan membaca dan keterampilan menulis. Satu keterampilan berbahasa saling terkait dengan keterampilan berbahasa lainya (Tarigan, 1998:1). Dalam penulisan ini peneliti menfokuskan pada keterampilan berbicara.

Keterampilan berbicara merupakan bidang pembelajaran yang sangat penting di samping keterampilan berbahasa yang lainnya, karena keterampilan berbicara siswa juga sangat mempengaruhi penilaian belajar siswa. Dalam lingkungan pendidikan, siswa dituntut terampil berbicara selama dalam proses pembelajaran. Siswa harus mampu mengutarakan gagasan, menjawab pertanyaan, mengajukan pertanyaan dengan baik sehingga siswa yang lain mengerti apa yang dimaksud dari pertanyaannya. Ketika melaksanakan diskusi, siswa dituntut terampil mengemukakan pendapat, mempertahankan pendapat, menyanggah pendapat siswa lain atau memperngaruhi siswa lain agar mengikuti alur pemikirannya (Nursidik, 2009:1).

Peneliti mengadakan wawancara dengan kepala sekolah tentang keterampilan berbicara, dari hasil wawancara tersebut terungkap bahwa siswa belum terampil berbicara (kurang lancar, merasa malu dan takut), ternyata pembelajaran keterampilan berbicara yang selama ini dilakukan hanya sebatas bertanya jawab dengan siswa. Salah satu upaya yang bisa digunakan untuk mengatasi masalah tersebut guru harus kreatif dalam melaksanakan proses pembelajaran. Hal ini dapat dilakukan dengan berbagai cara, salah satunya adalah dengan menggunakan berbagai media yang sesuai dengan tujuan pembelajaran, jenis tugas, dan respon yang diharapkan dikuasai siswa setelah pembelajaran berlangsung, dan konteks pembelajaran termasuk karakteristik siswa. Media dalam proses pembelajaran adalah segala sesuatu yang dapat dipergunakan untuk menyalurkan pesan, merangsang pikiran, perasaan, perhatian dan kemauan siswa, sehingga dapat mendorong untuk terlibat dalam proses pembelajaran (Robertus, 2007:1).

Manfaat media pembelajaran dalam proses pembelajaran adalah dapat membangkitkan keinginan siswa dan minat yang baru, membangkitkan motivasi dan rangsangan kegiatan belajar, dan bahkan membawa pengaruh-pengaruh psikologis terhadap siswa. Meskipun demikian dapat dikatakan bahwa salah salah satu fungsi utama media pembelajaran adalah sebagai alat bantu pembelajaran yang turut mempengaruhi iklim, kondisi, dan lingkungan belajar yang ditata dan diciptakan oleh guru. Selain menyajikan materi pembelajaran, guru juga hendaknya jeli dalam menentukan media pembelajaran yang akan digunakan, sebab media 
pembelajaran terbagi dalam beberapa macam yang penggunaannya disesuaikan dengan materi pembelajaran dan karakteristik siswa. Pemilihan dan penggunaan media yang tepat tentunya akan memaksimalkan hasil belajar siswa dan sesuai dengan yang diharapkan. Hal ini didukung oleh Bretz (dalam Yamin, 2005:154) membagi media menjadi tiga macam yaitu: media suara, media bentuk visual, dan media gerak. Media bentuk visual dibedakan menjadi tiga yaitu: gambar visual, garis (grafis dan symbol verbal). Adapun dalam penelitian ini akan digunakan media gambar seri. Gambar seri adalah kumpulan dari beberapa gambar yang menceritakan suatu kejadian atau peristiwa yang menarik yang disusun secara acak, atau berurut untuk dijadikan sebuah cerita (Arsyad, 2006:111). Selanjutnya Baugh (dalam Muhammad, 1998:30) mengemukakan tentang perbandingan peranan tiap alat indera kita. Semua pengalaman balajar yang dimiliki seseorang dapat di presentasikan yaitu: $90 \%$ diperoleh melalui indera lihat, 5\% melalui indera dengar, dan 5\% melalui indera lainnya. Pengalaman belajar manusia sebanyak $75 \%$ diperoleh melalui indera lihat, $13 \%$ melalui indera dengar dan selebihnya indera lainnya.

Menurut Basuki (1991:28) "media gambar seri dalam proses pembelajaran dapat berfungsi untuk: 1) mengembangkan kemampuan visual, 2) mengembangkan imajinasi, 3) membantu meningkatkan penguasaan siswa terhadap hal-hal yang abstrak, dan 4) mengembangkan kreatifitas siswa". Keuntungan pengunaan gambar seri menurut Sudjana (1997:71) yaitu: a) mudah dimanfaatkan di dalam pembelajaran karena praktis. b) harganya relatif murah dari jenis-jenis media pembelajaran yang lainnya, dan c) gambar seri dapat menerjemahkan konsep atau gagasan yang abstrak menjadi lebih realistik. Menurut Sudiman (2003:31) "ada beberapa syarat yang perlu dipenuhi dalam pengunaan gambar seri, yaitu: harus autentik, artinya gambar tersebut haruslah melukiskan situasi, sederhana komposisinya hendaklah cukup jelas menunjukkan poin-poin pokok dalam gambar, ukuran relative gambar dapat memperbesar atau memperkecil objek sebenarnya, gambar seri sebaiknya mengandung gerak atau perbuatan, gambar yang bagus belum tentu baik untuk mencapai tujuan pembelajaran".

Keefektifan penggunaan alat bantu gambar dalam proses pembelajaran dapat juga dilihat dari hasil penelitian Spauilding (dalam Muhammad, 1998:25) menguraikan tentang bagaimana siswa belajar melalui gambar sebagai berikut: 1) gambar merupakan perangkat pengajaran yang dapat menarik minat siswa, 2) gambar harus dikaitkan dengan kehidupan nyata, agar minat siswa menjadi efektif, dan 3) gambar membantu para siswa membaca buku pelajaran terutama dalam menafsirkan dan mengingat-ingat isi teks yang menyertainya. Penggunaan gambar seri dalam proses pembelajaran akan dapat menfokuskan perhatian siswa terhadap pembelajaran sehingga tidak membosankan dan dapat meningkatkan hasil belajar. Gambar seri juga dapat menarik minat siswa untuk mengungkapkan ide atau gagasan dalam bentuk lisan.

Pembelajaran berbicara melalui gambar seri dilakukan melalui tahapan seperti, a) perencanaan pelaksanaan pembelajaran keterampilan berbicara melalui media gambar seri. b) pelaksanaan pembelajaran keterampilan berbicara melalui media gambar seri. c) penilaian pembelajaran keterampilan berbicara melalui media gambar seri. Pembelajaran berbicara dalam pembelajaran berbahasa baru diperkenalkan secara formal dan tersruktur. Sedangkan tujuan umum dari pembelajaran keterampilan berbicara ini adalah agar siswa kelas III Sekolah Dasar terbiasa dalam berbicara sehingga nantinya dapat berbicara untuk menyampaikan ide, gagasan, maupun perasaannya kepada orang lain sehingga orang lain tahu apa yang menjadi tujuannya. Sedangkan tujuan khusus dari pembelajaran keterampilan berbicara adalah menyampaikan atau bercerita berdasarkan gambar seri yang dipajang di depan kelas sesuai dengan lafal dan intonasi yang tepat.

Berpijak dari latar belakang di atas, maka peneliti melakukan penelitian tindakan kelas yang mengimplementasikan media gambar seri dalam pembelajaran Bahasa Indonesia, khususnya pada materi keterampilan berbicara. Dengan perlakuan ini, diharapkan dapat meningkatkan hasil belajar siswa dalam pembelajaran matematika. Penelitian ini bertujuan untuk menjelaskan: (1) mendeskripsikan pengaruh implementasi media gambar seri terhadap proses pembelajaran Bahasa Indonesia siswa dan (b) mengetahui pengaruh implementasi pendekatan media gambar seri terhadap hasil belajar siswa.

\section{METODOLOGI PENELITIAN}

Penelitian ini akan dilaksanakan di di SDN 17 Batang Anai Kabupaten Padang Pariaman. SD ini terletak di dusun Kali Air Kanagarian Sungai Buluah Kecamatan Batang Anai. Dengan pertimbangan siswa kelas III di SDN 17 Batang Anai Kabupaten Padang Pariaman belum maksimal dalam pembelajaran keterampilan berbicara. Sebagai subjek dalam penelitian ini adalah siswa kelas siswa di kelas III SDN 17 Batang Anai Kabupaten Padang Pariaman yang berjumlah 30 orang. Dengan komposisi laki-laki 15 orang siswa dan perempuan 15 orang siswa. Jenis penelitian ini adalah penelitian tindakan kelas yang meliputi tahap perencanaan, pelaksanaan, pengamatan, dan refleksi. Data penelitian diperoleh melalui pencatatan lapangan, observasi, wawancara, dan hasil tes catatan lapangan pada dasarnya berisi deskripsi atau paparan tentang latar pengamatan terhadap tindakan praktek sewaktu pembelajaran berbicara melalui media gambar seri. Data yang 
diperoleh kemudian dianalisis dengan menggunakan pendekatan kualitatif dan kuatitatif karena peneliti ingin mengamati fenomena yang terjadi di dalam kelas.

\section{HASIL DAN PEMBAHASAN PENELITIAN}

\section{A. Hasil Penelitian \\ 1. Siklus I \\ a) Tahap Perencanaan}

Sebelum tindakan dilaksanakan terlebih dahulu peneliti membuat seperangkat pembelajaran (RPP). Standar kompetensi yang peneliti gunakan adalah keterampilan berbicara yaitu mengungkapkan pikiran, perasaan pengalaman, petunjuk dengan bercerita dan memberikan tanggapan/saran . Kompetensi dasar yang harus di kuasai siswa adalah mengomentari tokoh-tokoh cerita anak yang disampaikan secara lisan.

\section{b) Tahap Pelaksanaan}

Siklus I dilaksanakan dalam dua kali pertemuan dengan 2x3 menit di setiap pertemuannya. Proses pembelajaran keterampilan berbicara melalui media gambar seri dibagi menjadi tiga, yaitu kegiatan awal, kegiatan inti, kegiatan akhir. Dari gambaran proses pembelajaran yang telah berlangsung tersebut dapat disimpulkan bahwa siswa cukup mempunyai keberanian dalam mengemukakan pendapat dan idenya dalam menjawab pertanyaan-pertanyaan yang diberikan oleh guru. Begitupun dalam proses pemberian judul pada media gambar seri siswa sangat aktif dan berani dalam menjawab pertanyaan yang di ajukan oleh guru. Kondisi ini terbukti dengan banyaknya anak yang menunjuk tangan ketika diberi pertanyaan oleh guru.

\section{c) Tahap Pengamatan}

Pengamatan keberhasilan tindakan proses pembelajaran diamati selama dan sesudah tindakan dilaksanakan. Kegiatan ini dilakukan oleh observer kepala sekolah. Kepala Sekolah sebagai pengamat mengamati kegiatan yang dilakukan oleh guru, dan mengamati aspek kegiatan siswa. hal ini dilaksanakan untuk mendapatkan informasi dari guru, siswa, dan pengamat terhadap pelaksanaan proses pembelajaran yang berlangsung pada siklus I.

Penilaian proses keterampilan berbicara siswa melalui media gambar seri pada siklus I ini terlihat sebagai berikut yaitu: (1) keranian 3,37\%, (2) kelancaran 3,0\%, (3) kesesuaian isi cerita dengan gambar 2,6\%, (4) lafal dan intonasi $2,7 \%$. Keberhasilan ini berada pada taraf cukup. Dari keseluruhan penilaian proses tersebut dapat di uraikan bahwa 2 siswa mendapatkan kualifikasi sangat baik (jumlah nilai 16), 17 siswa mendapat kualifikasi baik (jumlah nilai 12-13), 7 siswa mendapat kualifikasi cukup (jumlah nilai 10-11), 4 siswa mendapat kualifikasi kurang (jumlah nilai 6-9). Dengan persentase masing-masing aspek yaitu keberanian 3,37:4 (aspek yang dinilai) x 100\% =84,25\%, kelancaran 3,0:4 (aspek yang dinilai) $\times 100 \%=$ $75 \%$, kesesuaian isi cerita dengan gambar 2,6:4 (aspek yang dinilai) x 100\% $=65 \%$, lafal dan intonasi 2,7:4 (aspek yang dinilai) x $100 \%=67 \%$. Memperoleh rata-rata kelas yaitu: 11,76 dengan persentase $73,5 \%$ (Cukup).

Penilaian hasil pada proses pembelajaran keterampilan berbicara melalui media gambar seri meliputi sebagai berikut: (1) mampu menjawab pertanyaan 3,3\%, (2) kelancaran membaca karangan 2,9\%, (3) kerapian tulisan 2,9\%, (4) penggunaan tanda baca 2,7\%. Dari keseluruhan penilaian hasil tersebut dapat di uraikan bahwa 3 siswa mendapatkan kualifikasi sangat baik (jumlah nilai 16), 16 siswa mendapat kualifikasi baik (jumlah nilai 12-14), 5 siswa mendapat kualifikasi cukup (jumlah nilai 10-11), 6 siswa mendapat kualifikasi kurang (jumlah nilai 7-9). Dengan persentase masing-masing aspek yaitu: mampu menjawab pertanyaan 3,3:4 (aspek yang dinilai) x 100\% = 82.5\%, kelancaran membaca karangan 3,0:4 (aspek yang dinilai) $\times 100 \%=72.5 \%$, kerapian tulisan 2,9:4 (aspek yang dinilai) x 100\% $=72,5 \%$, penggunaan tanda baca 2,7:4 (aspek yang dinilai) x 100\% $=67,5 \%$. Memperoleh rata-rata kelas yaitu: 11,77 dengan persentase nilai $73,5 \%(\mathrm{C})$.

Data-data tersebut memberi gambaran bahwa dari empat aspek yang dinilai ada satu aspek yang memperoleh nilai kurang yaitu aspek penggunaan tanda baca. Hal ini wajar karena siswa kelas III belum tahu banyak tentang pengunaan tanda baca yang tepat dan benar. Oleh sebab itu penilaian pengunaan tanda baca disini juga disesuaikan dengan kemampuan siswa yaitu hanya mencakup pengunaan tanda titik, koma, tanda tanya dan tanda seru. Namun, pada saat siswa tampil ke depan kelas untuk bercerita melalui media gambar seri masih ada sebahagian siswa tidak bisa bercerita bila tidak dibimbing melalui pertanyaan yang berkaitan dengan gambar.

Penilaian yang menyeluruh terhadap kegiatan proses pembelajaran berbicara melalui media gambar seri ini meliputi penilaian proses dan penilaian hasil. Penilaian tersebut lebih dirinci berdasarkan rata-rata sebagai berikut: (1) penilaian proses $11,76 \%$, dan (2) penilaian hasil 11,77\%. Dari rekapitulasi penilaian proses dan penilaian hasil tersebut dapat di uraikan masing-masing persentasenya sebagai berikut: penilaian 
proses 11,76:16 (nilai max) x 100\% = 73,5\%, penilaian hasil 11,77:16 (nilai $\operatorname{max)~} \mathrm{x} 100 \%=73,56 \%$, memperoleh rata-rata kelas yaitu: 11,77 dengan persentase nilai 73,56\% (Cukup). Data-data tersebut memberi gambaran bahwa dari empat aspek yang dinilai ada satu aspek yang memperoleh nilai kurang yaitu aspek keberhasilan siswa dalam mengikuti seluruh kegiatan proses pembelajaran berbicara melalui media gambar seri pada siklus I adalah $11,9 \%$.

\section{d) Tahap Refleksi}

Terlaksananya kegiatan proses pembelajaran merupakan implikasi dari pengunaan media yang menarik bagi siswa. Proses pembelajaran pada siklus I ini mengalami kendala dalam mengatasi keributan yang di karenakan jumlah siswa yang lumayan banyak yaitu 30 orang siswa dalam satu kelas tapi hal ini dapat di atasi dengan menerapkan metode belajar yang menyenangkan salah satunya dengan media gambar seri yang menarik dan ketika siswa sudah mulai jenuh maka peneliti sebagai guru meminta siswa menyanyikan salah satu lagu yang di sukai. Pada kegiatan proses pembelajaran, hasil pengamatan yang dilakukan kepala sekolah selaku pengamat terhadap peneliti, langkah-langkah yang dilakukan peneliti sudah sesuai dengan perencanaan. Hasil pengamatan sudah mencapai cukup baik. Guru sudah melakukan langkah-langkah pembelajaran sesuai dengan RPP. Hasil pengamatan dari pengamat dalam mengamati aktivitas siswa selama kegiatan pembelajaran belum maksimal. Hal ini disebabkan karena siswa belum faham terhadap langkahlangkah pembelajaran yang disebutkan oleh guru, ini terlihat banyak siswa yang bingung ketika siswa disuruh kedepan kelas untuk menceritakan media gambar seri.

Penilaian berbicara di fokuskan pada penilaian proses dan penilaian hasil. Penilain proses pembelajaran keterampilan berbicara melalui media gambar seri yaitu: keberanian siswa dalam bercerita, kelancaran dalam bercerita, kesesuaiaan isi cerita dengan gambar, dan lafal dan intonasi. Sementara penilaian hasil yaitu: kemampuan menjawab pertanyaan, kelancaran membaca karangan, kerapian tulisan, penggunaan tanda baca. Saat siswa tampil ke depan kelas untuk bercerita ada beberapa orang siswa yang hanya diam maka peran peneliti sebagai guru adalah memotivasi siswa dengan mengajukan pertanyaan-pertanyaan yang berkaitan dengan gambar agar siswa tersebut dapat menceritakan gambar melalui media gambar seri. Refleksi yang dilakukan pada siklus selanjutnya akan memberikan penekanan kepada siswa agar mampu menceritakan media gambar seri dengan bahasa sendiri dengan lafal dan intonasi yang sesuai.

\section{Siklus II}

\section{a) Tahap Perencanaan}

Hasil analisis refleksi pada siklus I menunjukkan keberhasilan penelitian belum mencapai tujuan yang diharapkan. Peneliti bersama kepala sekolah yang bertindak sebagai pengamat membuat perencanaan siklus II secara kolaboratif. Perencanan tindakan dibuat dalam bentuk RPP. Penyajian perencanaan tindakan siklus II membutuhkan waktu dua kali pertemuan dengan durasi masing-masing pertemuan 2x35 menit.

\section{b) Tahap Pelaksanaan}

Sama dengan pelaksanaan siklus I, proses pelaksanaan siklus II terbagi menjadi dua kali pertemuan. Proses pembelajaran keterampilan berbicara melalui media gambar seri dibagi menjadi tiga, yaitu kegiatan awal, kegiatan inti, kegiatan akhir.

\section{c) Tahap Pengamatan}

Penilaian pada proses pembelajaran berbicara meliputi kemampuan menjawab pertanyaaan, kelancaran membaca karangan, kerapian tulisan, dan penggunaan tanda baca. Penilaian hasil proses pembelajaran berbicara pada siklus II ini lebih dirinci berdasarkan rata-rata sebagai berikut: (1) mampu menjawab pertanyaan 3,3\%, (2) kelancaran membaca karangan 3,2\%, (3) kerapian tulisan 2,9\%, (4) penggunaan tanda baca $2,9 \%$. Keberhasilan siswa pada proses pembelajaran berbicara sebesar 13,1\%.

Dengan persentase masing-masing aspek yaitu keberanian 3,7:4 (aspek yang dinilai) x 100\% $=93 \%$, kelancaran 3,2:4 (aspek yang dinilai) x 100\% = 80\%, kesesuaian isi cerita dengan gambar 3,1:4 (aspek yang dinilai) $\times 100 \%=78 \%$, lafal dan intonasi 3,2:4 (aspek yang dinilai) x $100 \%=80 \%$. Memperoleh rata-rata kelas yaitu: 13,2 dengan persentase nilai 83,\%. Dari uraian penilaian hasil dapat diketahui bahwa 7 siswa mendapatkan kualifikasi sangat baik (jumlah nilai 15-16), 7 belas siswa mendapat kualifikasi baik (jumlah nilai 12-14), 4 siswa mendapat kualifikasi cukup (jumlah nilai 10-11), 2 siswa mendapat kualifikasi kurang (jumlah nilai 9). Data-data tersebut memberi gambaran bahwa dari empat aspek yang dinilai secara keseluruhan telah mendapat nilai yang baik sesuai dengan yang diharapkan. Bila ditinjau dari rujukan keberhasilan maka keberhasilan ini berada dalam taraf baik.

Penilaian yang menyeluruh terhadap kegiatan proses pembelajaran berbicara melalui media gambar seri ini meliputi penilaian proses dan penilaian hasil. Penilaian tersebut lebih dirinci berdasarkan rata-rata sebagai berikut: (1) penilaian proses 13,2\%, dan (2) penilaian hasil 13,1\%. Keberhasilan siswa dalam mengikuti seluruh kegiatan proses pembelajaran berbicara melalui media gambar seri pada siklus II adalah $13,2 \%$. Dengan persentase masing-masing aspek yaitu penilaian proses 13,2:16 (nilai $\max ) \times 100 \%=83 \%$, 
penilaian hasil 13,1:16 (nilai $\operatorname{max)}$ x $100 \%=82 \%$. Memperoleh rata-rata kelas yaitu: 13,2 dengan persentase nilai $83, \%$. Dari uraian rekapitulasi penilaian dapat diketahui bahwa delapan siswa mendapatkan kualifikasi sangat baik (jumlah nilai 14,5-16), delapan belas siswa mendapat kualifikasi baik (jumlah nilai 12-14), empat siswa mendapat kualifikasi cukup (jumlah nilai 10,5-11,5). keberhasilan ini berada dalam taraf baik

Berdasarkan hasil pengamatan, dapat diperoleh gambaran bahwa hasil pembelajaran berbicara melalui media gambar seri adalah sebagai berikut: nilai tertinggi pada siklus II adalah 16 dan nilai terendah adalah 10,5. Dari data rekapitulasi penilaian proses dan penilaian hasil persentase ketuntasan yang diperoleh adalah $86 \%$ dan yang tidak tuntas adalah $13 \%$ dengan 26 orang siswa yang tuntas dan 4 orang siswa yang tidak tuntas. Berdasarkan data tersebut dapat disimpulkan bahwa pembelajaran pada siklus II mengalami peningkatan jika dibandingkan dari siklus I dan penilaian yang di capai pada siklus II adalah $86 \%$ sudah mencapai ketuntasan. Dimana sudah melebihi ketuntasan yang ditetapkan oleh BNSP 2006 yaitu $75 \%$.

\section{d) Tahap Refleksi}

Berdasarkan hasil pengamatan dan pencatatan lapangan, siklus II sudah terlaksana dengan baik. Pelaksanaan pembelajaran melalui media gambar seri sudah terlaksana oleh guru sesuai dengan langkahlangkah pembelajaran yang tercantum dalam RPP. Jadi, penelitian tindakan kelas ini dicukupkan sampai siklus II.

\section{B. Pembahasan}

\section{Pembahasan Siklus I}

Pelaksanaan proses pembelajaran keterampilan berbicara melalui media gambar seri untuk meningkatkan keterampilan berbicara siswa di kelas III terdiri dari kegiatan awal, kegiatan inti, dan kegiatan akhir. Kegiatan awal berupa mempersiapkan situasi, kondisi, sarana dan prasarana untuk proses pembelajaran. Kemudian guru menyampaikan tujuan pembelajaran agar proses pembelajaran menjadi terarah dan sistematis di mana tujuan pembelajaran adalah siswa mampu menceritakan media gambar seri dengan bahasa sendiri. Pelaksanaan pembelajaran yang kreatif dan menyenangkan sangat dibutuhkan oleh siswa terutama pada kelas III. Berdasarkan catatan dilapangan dan diskusi peneliti dengan kepala sekolah sebagai kolaborator dan observer, ternyata siswa memiliki kemampuan dalam hal sebagi berikut: (1) menyebutkan cara membuat alat pembersih debu yang terdapat dalam setiap gambar seri, (2) mengurutkan gambar seri sesuai urutan yang benar, (3) menentukan judul media gambar seri, (4) menceritakan media gambar seri dengan bahasa sendiri. Umumnya kemampuan siswa dalam menceritakan media gambar seri meningkat baik dari segi keberanian dalam bercerita, kelancaran dalam bercerita, kesesuaian isi cerita dengan media gambar seri, maupun penggunaan lafal dan intonasi. penyebabnya munculnya kemampuan dari siswa karena penggunaan media gambar seri yang menarik, dekat dengan kehidupan siswa serta pemberian motivasi yang tiada henti dari guru.

Keefektifan penggunaan media gambar seri juga diperkuat oleh hasil penelitian Spaulding (dalam Robertus, 2008:5) menguraikan tentang bagaimana siswa belajar melalui gambar sebagai berikut: (1) gambar merupakan pengajaran yang dapat menarik minat siswa secara efektif, (2) gambar harus dikaitkan dengan kehidupan nyata, (3) gambar membantu siswa lebih memahami materi yang akan dipelajarinya. Pembelajaran keterampilan berbicara seperti yang telah peneliti lakukan dalam penelitian ini belum pernah dilaksanakan sebelumnya. Hal ini berdampak pada siswa yang tidak tertarik pada pembelajaran keterampilan berbicara yang diberikan karena bersifat abstrak, sehingga keterampilan berbicara siswa tidak dapat meningkat secara optimal.

Penilaian yang dilakukan pada saat siswa berbicara melalui media gambar seri dengan bahasa sendiri dengan lafal dan intonasi yang sesuai. Penilaian berlangsung secara objektif. Merujuk kepada analisis penelitian siklus I, nilai rata-rata terhadap keterampilan berbicara siswa adalah 11,9. Berdasarkan hasil pengamatan siklus I yang diperoleh masih ada 14 orang siswa yang memperoleh nilai kurang. Berdasarkan jumlah ketuntasan perorangan maka ketuntasan belajar yang tercapai hanya 53,3\%. Sementara standar ketuntasan belajar menurut BSNP (2006:12) adalah sebesar 75\%. Jadi dapat disimpulkan penelitian yang dilakukan pada siklus I masih belum mencapai standar ketuntasan yang diharapkan sesuai dengan BSNP, oleh sebab itu peneliti melakukan siklus II dengan harapan akan dapat lebih meningkatkan keterampilan berbicara siswa melalui media gambar seri di kelas III tersebut.

Berdasarkan data-data dari hasil pengamatan pada siklus I peneliti merasa sangat perlu untuk melakukan persiapan perencanaan pelaksananaan pembelajaran dengan semua komponen-komponen untuk dilaksanakan pada siklus II dengan harapan guru dapat lebih meningkatkan keterampilan berbicara siswa melalui media gambar seri.

Proses penyampaian materi pembelajaran keterampilan berbicara yang berlangsung selama ini hanya meminta siswa menceritakan tentang pengalamannya dengan cara melakukan tanya jawab. Padahal proses pembelajaran dapat dilakukan dengan lebih kreatif agar menyenangkan bagi siswa yaitu dengan cara 
menggunakan media yang lebih variatif dan pembelajaran yang tidak monoton dengan cara memberi waktu bagi siswa untuk melakukan kegiatan yang menyenangkan seperti bernyanyi sambil bertepuk tangan. Untuk itu di harapkan guru lebih memahami komponen-komponen persiapan mengajar.

\section{Pembahasan Siklus II}

Pelaksanaan proses pembelajaran keterampilan berbicara melalui media gambar seri untuk meningkatkan keterampilan siswa di kelas III terdiri dari kegiatan awal, kegiatan inti, dan kegiatan akhir. Pada kegiatan awal dilakukan persiapan sarana dan prasarana serta menyampaikan tujuan pembelajaran yaitu siswa mampu menceritakan gambar seri dengan bahasa sendiri. Berdasarkan catatan dilapangan dan diskusi peneliti dengan kepala sekolah sebagai kolaborator dan observer, ternyata siswa memiliki kemampuan dalam hal sebagai berikut: (1) menyebutkan cara menggunakan alat pembersih debu yang terdapat dalam setiap gambar seri, (2) mengurutkan gambar seri sesuai urutan yang benar, (3) menentukan judul media gambar seri, (4) menceritakan media gambar seri dengan bahasa sendiri. Umumnya kemampuan siswa dalam menceritakan media gambar seri meningkat, baik dari segi keberanian dalam bercerita, kelancaran dalam bercerita, kesesuaian isi cerita dengan media gambar seri, maupun penggunaan lafal dan intonasi. Penyebab munculnya kemampuan dari siswa karena penggunaan media gambar seri yang menarik, dekat dengan kehidupan siswa serta pemberian motivasi yang tiada henti dari guru.

Sebelumnya peneliti tidak pernah menggunakan media khususnya media gambar seri yang dekat dengan kehidupan dan dunia anak-anak pada pembelajaran keterampilan berbicara. Akhirnya siswa tidak tertarik pada pembelajaran yang diberikan karena bersifat abstrak, sehingga keterampilan berbicara siswa tidak berani dan tidak dapat meningkat kan keterampilan berbicara siswa secara optimal. Hal ini didukung oleh Baugh (dalam Muhammad, 2008:01) "tentang perbandingan peranan alat indera manusia, semua pengalaman belajar yang dimiliki seseorang dapat dipresentasikan sebagai berikut: $90 \%$ diperoleh melalui indera lihat, 5\% melalui indera dengar, dan 5\% melalui indera lainnya. kegiatan akhir pelaksanaan proses pembelajaran berbicara di akhiri dengan menyampaikan pesan-pesan moral dan menyimpukan pembelajaran.

Penilaian dilakukan pada saat siswa berbicara yaitu penilaian proses aspek keterampilan berbicara yang terdiri dari empat point yakni: (1) keranian dalan bercerita, (2) kelancaran dalam bercerita, (3) kesesuaian isi cerita dengan gambar, dan (4) lafal dan intonasi. Sementara penilaian hasil berupa penilaian dari latihan dan tugas-tugas yang telah dikerjakan oleh siswa yang terdiri dari empat point yakni: (1) kemampuan menjawab pertanyaan, (2) kelancaran membaca karangan, (3) kerapian tulisan, dan (4) penggunaan tanda baca. Berdasarkan data-data penilaian proses dan penilaian hasil pada siklus I, nilai ratarata yang diperoleh siswa adalah $11,9 \%$, dengan empat belas orang siswa yang memiliki jumlah nilai kurang dari 12 dengan persentase ketuntasan 53,3\% sementara target ketuntasan yang ingin dicapai yaitu 75\%. Untuk itu hasil refleksi penilaian dari siklus I dilanjutkan ke siklus II, dan hasil penilaian proses dan penilaian hasil dalam keterampilan berbicara melalui medai gambar seri pada siklus II sudah mencapai ketuntasan dengan rata-rata $13,2 \%$, dengan persentase ketuntasan $86 \%$. Dari nilai yang diperoleh pada siklus I dan siklus II mengalami peningkatan. Jadi dapat dikatakan bahwa guru sudah berhasil dalam membelajarkan siswa, dapat dilihat dari hasil penilaiannya. Jadi, penilaian terhadap proses dan hasil belajar siswa dapat memberikan gambaran tentang kemampuan masing-masing siswa terhadap proses pembelajaran keterampilan berbicara melalui media gambar seri dengan bahasa sendiri dengan menggunakan lafal dan intonasi yang sesuai. Hal ini semakin mendukung pendapat Basuki (1991:28) yang menyatakan bahwa media gambar seri dalam proses pembelajaran dapat berfungsi untuk: 1) mengembangkan kemampuan visual, 2) mengembangkan imajinasi, 3) membantu meningkatkan penguasaan siswa terhadap hal-hal yang abstrak, dan 4) mengembangkan kreatifitas siswa.

\section{KESIMPULAN DAN SARAN KESIMPULAN}

Berdasarkan hasil penelitian dan pembahasan yang telah dipaparkan sebelumnya, maka peneliti menyimpulkan hal-hal sebagai berikut.

1. Meningkatkan keterampilan berbicara dapat dilakukan melalui media gambar seri dengan cara menceritakan media gambar seri dengan bahasa sendiri dengan lafal dan intonasi yang sesuai.

2. Peningkatan keterampilan berbicara siswa juga didukung oleh persiapan perencanaan pelaksanaan pembelajaran berdasarkan kurikulum dan segala komponen-komponen pendukungnya, yang terdiri dari indikator, langkah-langkah pembelajaran, media dan penilaian.

3. Pelaksanaan proses pembelajaran keterampilan berbicara melalui media gambar seri dimulai dari kegiatan awal, kegiatan inti, dan kegiatan akhir. Selama dalam proses pembelajaran keterampilan berbicara melalui media gambar seri guru juga mengajak siswa bernyanyi dengan menyanyikan 
lagu yang dikenal dan disukai oleh siswa yang bertujuan untuk mengatasi kejenuhan yang dialami oleh siswa.

4. Penilaian dilakukan baik penilaian proses maupun penilaian hasil selama proses pembelajaran keterampilan berbicara melalui media gambar seri berlangsung. Penilaian ini bertujuan agar dapat memberikan gambaran kemampuan masing-masing siswa, mendiagnosa kesulitan belajar yang dialami siswa, memberikan umpan balik untuk perbaikan proses pembelajaran selanjutnya.

\section{SARAN}

Berdasarkan kesimpulan yang telah dicantumkan di atas, maka peneliti mengajukan beberapa saran untuk dipertimbangkan:

1. Semua guru, hendaknya dapat meningkatkan keterampilan berbicara siswa dengan melakukan persiapan pembelajaran yang maksimal.

2. Hendaknya pelaksanaan proses pembelajaran keterampilan berbicara dan menceritakan media gambar seri dengan bahasa sendiri dapat digunakan di semua kelas rendah.

3. Proses penilaian hendaknya dilakukan seobjektif mungkin pada semua siswa.

\section{DAFTAR PUSTAKA}

Arsyad, Azhar. 2006. Media Pembelajaran. Jakarta: PT Raja Grafindo Persada

Asdam, Muhammad. 2008. Efektivitas Penggunaan Media Gambar Seri Dalam Penulisan Karangan Pada Siswa Sekolah Dasar. (online) Http://www.bpgupg.go.id/index.php?view=article\&id= $143 \%$ Aefektivitas-penggunaan-media-gambar-seri-dalam-penulisan-karangan-pada-siswa-sekolahdasar\&option=com_content\&itemid=144. Diakses 18 Juli 2008

Basuki, Wibaya. 1991. Media Pengajaran. Jakarta: Departemen Pendidikan dan Kebudayaan Direktorat Jendral Pendidikan Proyek Pembinaan Tenaga Kependidikan

Martinis, Yamin. 2005. Taktik Pengembangan Kemampuan Siswa. Jakarta: GP Press

Nursidik, Yahya. 2009. Pengertian Media. (online) Http://apadefenisinya.blogspot.com/2007/12/pengertianmedia.html. Diakses 15 Desember 2009

Robertus dan Kosasih. 2007. Media Pembelajaran. (online) http://neozonk. blokspot.com/2007/11/rangkuman-buku-media-pembelajaran.html. Diakses 9 Mei 2009.

Sudiman, Arif. 2003. Media Pendidikan. Jakarta: PT. Raja Grafindo Persada

Sudjana, Nana dan Ahmad Riva'i. 1997. Media Pengajaran. Bandung: CV. Sinar Bandung

Tarigan, Hendri Guntur. 1998. Teknik Pengajaran Keterampilan Berbahasa. Bandung: Angkasa 